\title{
Fungi associated with disease symptoms on Pinus mugo needles in the Polish Tatra Mountains
}

\author{
Czesław Bartnik ${ }^{1 *}$, Tadeusz Kowalski ${ }^{1}$, Piotr Bilański ${ }^{1}$ \& Tomasz Zwijacz-Kozica²
}

\section{Article info}

Received: 1 Jun. 2021

Revision received: 25 Jun. 2021

Accepted: 29 Jun. 2021

Published: 30 Jul. 2021

\section{Associate Editor}

Marcin Piątek

\begin{abstract}
Dwarf mountain pine, Pinus mugo, is an important component of the subalpine and alpine zone in Europe. For several years, in one of the natural areas of the occurrence of this species in the Polish Tatras, an intensified decline of the assimilation apparatus has been observed. The studies conducted in 2016-2020 were aimed at determining the types of disease symptoms occurring on $P$. mugo needles and at identifying the species composition of fungi within symptomless and diseased needles. We isolated 57 taxa from 6 types of disease symptoms and from needles without disease symptoms, identified on the basis of morphological features and molecular analyses. Absolute parasites were represented by only one species of Coleosporium senecionis, which was identified by the aecium stage. The genus Lophodermium was represented by three species: L. conigenum, L. corconticum and L. pini-mugonis. So far, L. corconticum was known only from the Karkonosze Mountains in Poland, and L. pini-mugonis from the German Alps. In addition, the more frequently isolated species included: Sydowia polyspora, Hendersonia sp., Nemania serpens, Leptomelanconium allescheri, Cladosporium spp., Biscogniauxia nummularia and Alternaria spp. Some taxa were associated with only one type of disease symptom, while some species of fungi were found to be associated with different symptoms. Twelve species of fungi were isolated from living symptomless needles, some of which were subsequently found in association with nectrotic areas on needles, e.g., Lophodermium corconticum, L. conigenum and Leptomelanconium allescheri. L. pinastri has not been found in the present studies. In the discussion, an attempt was made to assess the role of some of the identified species of fungi in causing the disease process of $P$. mugo needles.
\end{abstract}

Key words: dwarf mountain pine, endophytes, needle diseases, Lophodermium corconticum, Lophodermium pini-mugonis, Lophodermium conigenum

\section{Introduction}

Dwarf mountain pine, Pinus mugo, is a key element in the sub-alpine flora of many mountain ranges of Europe (Boratyńska 2002; Boratyńska et al. 2005). In the Tatra Mountains, this shrub grows mainly above the mountain zone at an altitude of 1550-1850 m a.s.l. (Boratyńska 2002). P. mugo plays an important role in preventing avalanches and soil erosion in high mountains (Ballian et al. 2016). It also helps to maintain favorable thermal conditions of the soil and reduces the effects caused by frost weathering. As a pioneering species, P. mugo inhabits areas damaged by landslides, avalanches and human activity (Mróz \& Perzanowska 2004). For these reasons, this species is currently under legal protection in Poland.

In various areas of $P$. mugo occurrence, research is carried out on the participation of fungi in reducing the

\footnotetext{
1 Department of Forest Ecosystems Protection, University of Agriculture in Kraków, al. 29 Listopada 46, 31-425 Kraków, Poland

2 Tatra National Park, Kuźnice 1, 34-500 Zakopane, Poland

* Corresponding author e-mail: rlbartni@cyf-kr.edu.pl
}

health condition of this species, growing in relatively difficult environmental conditions (Schnell 1987). Known diseases of $P$. mugo needles include, in particular, red band disease caused by Dothistroma septosporum and brown spot needle blight caused by Mycosphaerella dearnessii (anam. Lecanosticta acicola) (Pehl \& Butin 1992; Maschning \& Pehl 1994; Holdenrieder \& Sieber 1995; Pehl 1995; La Porta \& Capretti 2000; Bednářová et al. 2006; Boroń et al. 2016). P. mugo has also been shown as a host to the recently described new species Dothistroma pini (Barnes et al. 2011). P. mugo needles are also often infested by fungi of the genus Lophodermium (Andjelič 2000; Hirose \& Osono 2006; Hou et al. 2009). This phenomenon is characteristic also for other tree species of the genus Pinus (Minter \& Millar 1980; Ortiz-García et al. 2003; Salas-Lizana \& Oono 2018). In some studies, considerable attention was paid to P. mugo needle endophytic fungi. The following fungi are mainly shown as $P$. mugo needle endophytes: Cenangium ferruginosum, Cyclaneusma minus, C. niveum, Lophodermium 
pinastri and Sydowia polyspora (= Hormonema dematioides) (Schnell 1987; Hata \& Futai 1995; Sieber et al. 1999). Some of them, under stressful conditions, cause premature dying off and dropping of needles (Sieber 2007; Giordano \& Gonthier 2011).

In Poland, research on $P$. mugo needle diseases is relatively sparse. One of the first observations was made in the Tatra National Park by Lutyk (1978), who found the presence of several species of fungi on the needles of this shrub, of which he considered L. pinastri to be the most dangerous. Results of later studies conducted by Pusz et al. (2015) also come from this region. The authors found frequent presence of yellow spots on the needles. In the needles from all stands, they isolated large numbers of $L$. conigenum and to a lesser extent $L$. pinastri. In similar studies in the Karkonosze National Park (Pusz et al. 2013), the presence of L. pinastri and Lophodermium sp., which was later described as a new species $L$. corconticum (Koukol et al. 2015), was observed. Research by Kowalski et al. (2018) led to the first identification of the presence of the pathogenic fungus Leptomelanconium allescheri on the needles of $P$. mugo in the Tatra National Park and the description of the accompanying disease symptoms. Results of previous studies show that the emerging health problems of mountain pine needles growing at higher altitudes may be the result of activities of the various pathogenic fungi. The relatively poor identification of the species composition of fungi present in the P. mugo needle in Poland and observation in recent years of increased occurrence of diseases prompted the undertaking of further research in this field.

The aim of this study was: i) to determine the species composition of fungi inhabiting $P$. mugo needles with symptoms of necrosis and discoloration, and for comparison - fungi in living symptomless needles; ii) determination of the species of fungi for the distinguished types of discoloration; iii) examining selected species of fungi using molecular techniques and phylogenetic analysis.

\section{Material and methods}

The research was carried out on seven selected plots located in the Western Tatras within the Chochołowska Valley (Table 1; Fig. 1). The plant material was collected during the growing season (May, July, September and November) in 2016, 2017 and 2020. Samples were collected at different weather conditions. In total, 35 randomly selected shoots, each $50 \mathrm{~cm}$ long, from 35 P. mugo bushes were collected. Shoots were packed separately in polyethylene bags and transported directly to the laboratory, where they were stored at $5^{\circ} \mathrm{C} .23,500$ double needles from 3 years $(30 \%$ of all needles on the shoots) were analyzed for necrosis and discoloration and the percentage of needles with symptoms was calculated. A detailed analysis of the symptoms of diseases on the needles resulted in the identification of 7 types of needles: needles without symptoms; needles with numerous yellow and yellow-brown spots; needles with a brown spot or

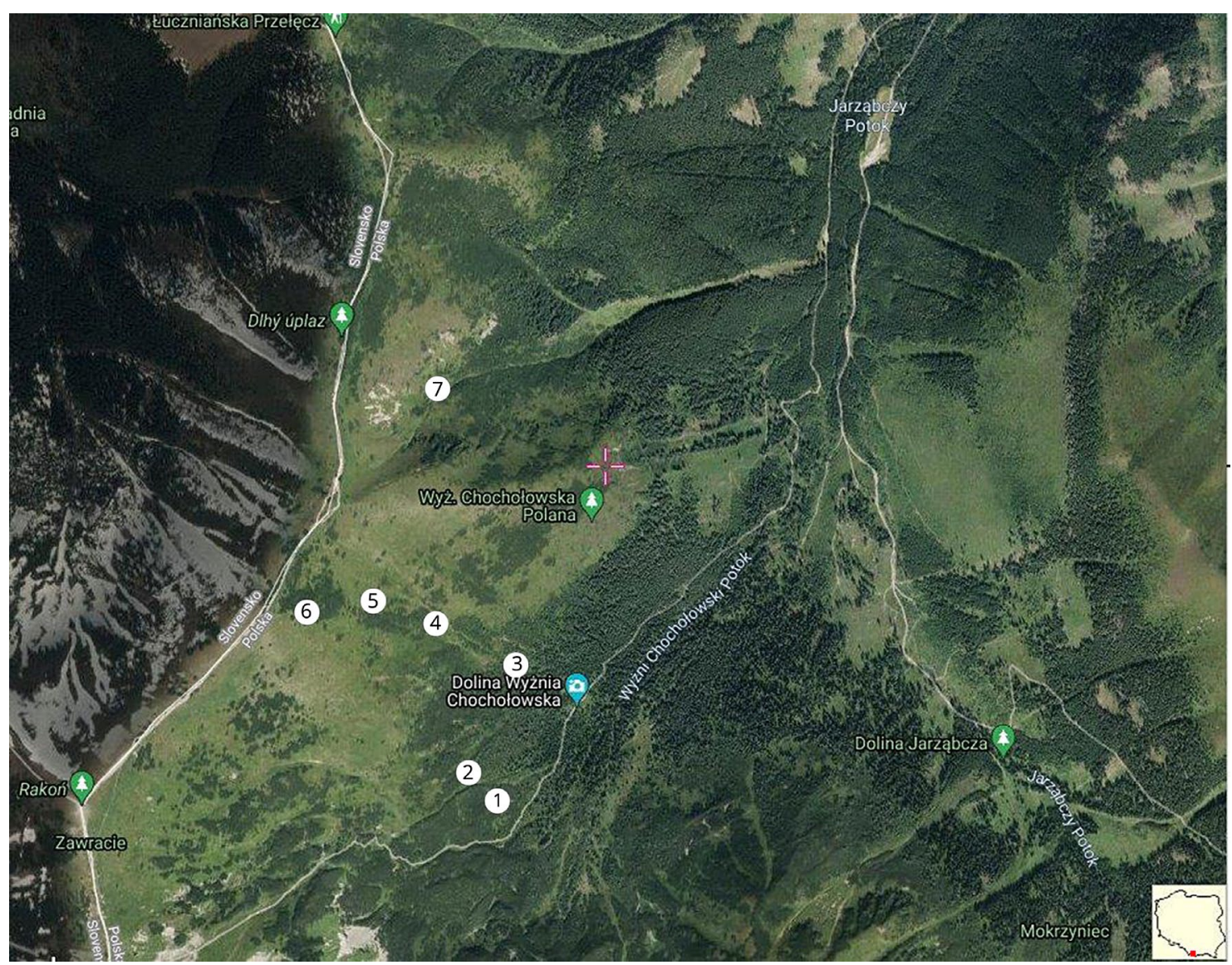

Figure 1. Distribution of seven research plots in the Western Tatras, a map was adapted (see also Map of Polish Tatra Mountains, available online: https://mapa.szukacz.pl) 
Table 1. Characteristic of study plots.

\begin{tabular}{c|c|c|c|c}
\hline $\begin{array}{l}\text { Plot } \\
\text { number }\end{array}$ & Location & $\begin{array}{c}\text { Altitude } \\
\text { (m a.s.1.) }\end{array}$ & $\begin{array}{c}\text { Clump } \\
\text { surface } \\
\text { (are) } \\
\text { (a) }\end{array}$ & $\begin{array}{c}\text { Mean percentage } \\
\text { of needles with } \\
\text { discoloration and } \\
\text { necrosis (\%) }\end{array}$ \\
\hline 1 & $\begin{array}{r}49^{\circ} 12^{\prime} 57^{\prime \prime} \mathrm{N} ; \\
19^{\circ} 46^{\prime} 11^{\prime \prime} \mathrm{E}\end{array}$ & 1556 & 5.5 & 44 \\
\hline 2 & $\begin{array}{r}49^{\circ} 12^{\prime} 59^{\prime \prime} \mathrm{N} ; \\
19^{\circ} 46^{\prime} 08^{\prime \prime} \mathrm{E}\end{array}$ & 1582 & 5.5 & 50 \\
\hline 3 & $\begin{array}{r}49^{\circ} 13^{\prime} 03^{\prime \prime} \mathrm{N} ; \\
19^{\circ} 46^{\prime} 05^{\prime \prime} \mathrm{E}\end{array}$ & 1624 & 4.3 & 45 \\
\hline 4 & $\begin{array}{r}49^{\circ} 13^{\prime} 05^{\prime \prime} \mathrm{N} ; \\
19^{\circ} 46^{\prime} 00^{\prime \prime} \mathrm{E}\end{array}$ & 1667 & 3.0 & 50 \\
\hline 5 & $\begin{array}{r}49^{\circ} 13^{\prime} 08^{\prime \prime} \mathrm{N} ; \\
19^{\circ} 45^{\prime} 55^{\prime \prime} \mathrm{E}\end{array}$ & 1737 & 4.6 & 65 \\
\hline 6 & $\begin{array}{r}49^{\circ} 13^{\prime} 09^{\prime \prime} \mathrm{N} ; \\
19^{\circ} 45^{\prime} 53^{\prime \prime} \mathrm{E}\end{array}$ & 1746 & 5.1 & 58 \\
\hline 7 & $\begin{array}{r}49^{\circ} 13^{\prime} 50^{\prime \prime} \mathrm{N} ; \\
19^{\circ} 46^{\prime} 14^{\prime \prime} \mathrm{E}\end{array}$ & 1592 & 1.5 & 51 \\
\hline
\end{tabular}

streaked necrosis, then associated with a dead top; dead needles with only a viable epiphyseal part remaining; needles completely dead, attached to the shoots; needles alive, with necrosis progressing from the base; needles with numerous irregular whitish-yellow spots. In order to identify the fungi accompanying the symptoms of the disease, both etiological signs on necrotic tissues were examined, and needle isolation was also performed. Isolation of fungi was carried out with 520 needles (2060 needle fragments) considering each type described above. Observations of conidiomata structure and measurements of morphological structures were made using the Zeiss Discovery V12 stereomicroscope and the Zeiss Axiophot light microscope with differential interference contrast (DIC) illumination. Appropriate literature and mycological keys were used for the analyses (Sutton \& Chao 1970; Minter \& Millar 1980; Sutton 1980; Minter 1981; Vujanovic \& St-Arnaud 2001; Hou et al. 2009). For groups of identical isolates, one or more representative cultures were selected for molecular analysis.

On the basis of 23,500 needles analyzed, the percentage of needles with discoloration and necrosis was calculated for the each study plot (Table 1). In order to determine the incidence of vesicular rust in pine needles, 3691 needles were analyzed on five randomly selected shoots, and then the percentage of needles with aecions and symptoms remaining after aecions was determined.

Needles with necrotic discoloration and without discoloration were surface sterilized by soaking first for $1 \mathrm{~min}$ in $96 \%$ ethanol, then $30 \mathrm{~s}$ in a solution of sodium hypochlorite (approx. 4\% available chlorine) and finally for $30 \mathrm{~s}$ in $96 \%$ ethanol and $3 \mathrm{~min}$ in sterile water followed by drying in layers of blotting paper and removal of superficial tissue. Next six small fragments were cut out from one sample and placed in the Petri dishes $(9 \mathrm{~cm})$ on malt extract agar supplemented with tetracycline (MEA+T medium: 20 g/L malt extract, $15 \mathrm{~g} / \mathrm{L}$ agar, Difco, Sparks, MD, USA; $200 \mathrm{mg} / \mathrm{L}$ tetracycline, TZF Polfa, Poland). The MEA $+\mathrm{T}$ cultures were incubated in the dark for 10 weeks at $20^{\circ} \mathrm{C}$ and controlled every 5-8 days for the occurrence of sporulation.

\section{Molecular analyses}

Samples for genetic analysis were prepared for three types of fungal material according to the procedure by Kowalski et al. (2018). Total genomic DNA was extracted using Genomic Mini AX Plant (A\&A Biotechnology, Gdynia, Poland) according to the manufacturer's protocol, and diluted DNA extracts were used as templates in PCR. The molecular identification of fungi was performed by comparing the sequences of the ITS regions of rDNA.

In our study the ITS rDNA region (ITS1-5.8S-ITS2) was amplified with the primers ITS4 and ITS5 (White et al. 1990). DNA fragments were amplified in a total volume of $25 \mu \mathrm{l}$ containing: $0.25 \mu \mathrm{l}$ of Phusion Green High-Fidelity DNA Polymerase Thermo Scientific (Fermentas, Finnzymes, Pierce, Abgene), $5 \mu$ l Phusion HF buffer $(5 \times), 0.5 \mu \mathrm{l}$ of dNTPs $(10 \mathrm{mM}), 0.75 \mu \mathrm{l}$ DMSO $(100 \%)$ and $0.5 \mu \mathrm{l}$ of each primer $(25 \mu \mathrm{M})$. Amplifications were run in a Thermycler Biometra T-Personal 48 (Biometra $\mathrm{GmbH}$, Goettingen, Germany) with 35 cycles comprising $30 \mathrm{~s}$ denaturation at $98^{\circ} \mathrm{C}, 10 \mathrm{~s}$ annealing at $52-56^{\circ} \mathrm{C}$ (depending on the primer melting temperature and fungal species) and $30 \mathrm{~s}$ at $72^{\circ} \mathrm{C}$, and a final elongation step at $72^{\circ} \mathrm{C}$ for $8 \mathrm{~min}$. PCR effectiveness was verified by $2 \%$ agarose gel electrophoresis stained with Midori Green Advance DNA Stain (Nippon Genetic Europe), and positive amplification products were purified with a Clean-Up DNA purification kit (A\&A Biotechnology, Gdynia, Poland). Bidirectional sequencing of purified products was carried out with the use of PCR primers. Amplified products were sequenced with the BigDye Terminator v 3.1 Cycle Sequencing Kit (Applied Biosystems, Foster City, CA, USA) and the products were resolved with a ABI PRISM 3100 Genetic Analyzer (Applied Biosystems), at the DNA Research Centre (Poznań, Poland) using the same primers that were used for the PCR. The obtained barcode sequences were processed with Chromas Pro 1.6 software (Technelysium, Australia) and queried against the NCBI GenBank database with the BLAST search tool to retrieve the most similar sequences.

\section{Phylogenetic analyses}

Phylogenetic analyses were conducted only for Lophodermium spp. BLAST searches using the BLASTn algorithm were performed to retrieve similar ITS sequences from Gen-Bank (http://www.ncbi.nlm.nih.gov) and accession numbers for these sequences are presented in the phylogenetic tree (Fig. 2). Datasets were curated with the MEGA X program (Kumar et al. 2018). The ITS dataset included all available sequences for reference species previously used by (Koukol et al. 2015) that could be retrieved from Gen-Bank (Fig. 2) to show the placement of our isolates within this genus. The outgroup taxon for the ITS dataset analysis was Colpoma quercinum.

ITS dataset were aligned online using MAFFT v 7 (Katoh \& Standley 2013) with the E-INS-i option, a gap-opening penalty of 1.53 and an offset value of 0.00 . The alignments were checked manually with BioEdit 
v.2.7.5 (Hall 1999) to ensure the correct alignment of intron, ITS1 and ITS2 regions. Introns were excluded from further phylogenetic analyses. Then, the dataset were tested using the corrected Akaike information criterion (AICc) for the best fitted substitution model in jModelTest
2.1.10 (Guindon \& Gascuel 2003; Darriba et al. 2012) and analysed in terms of maximum likelihood (ML) and Bayesian inference (BI).

Phylogenetic trees were inferred for each of the datasets using three different methods: Maximum likelihood
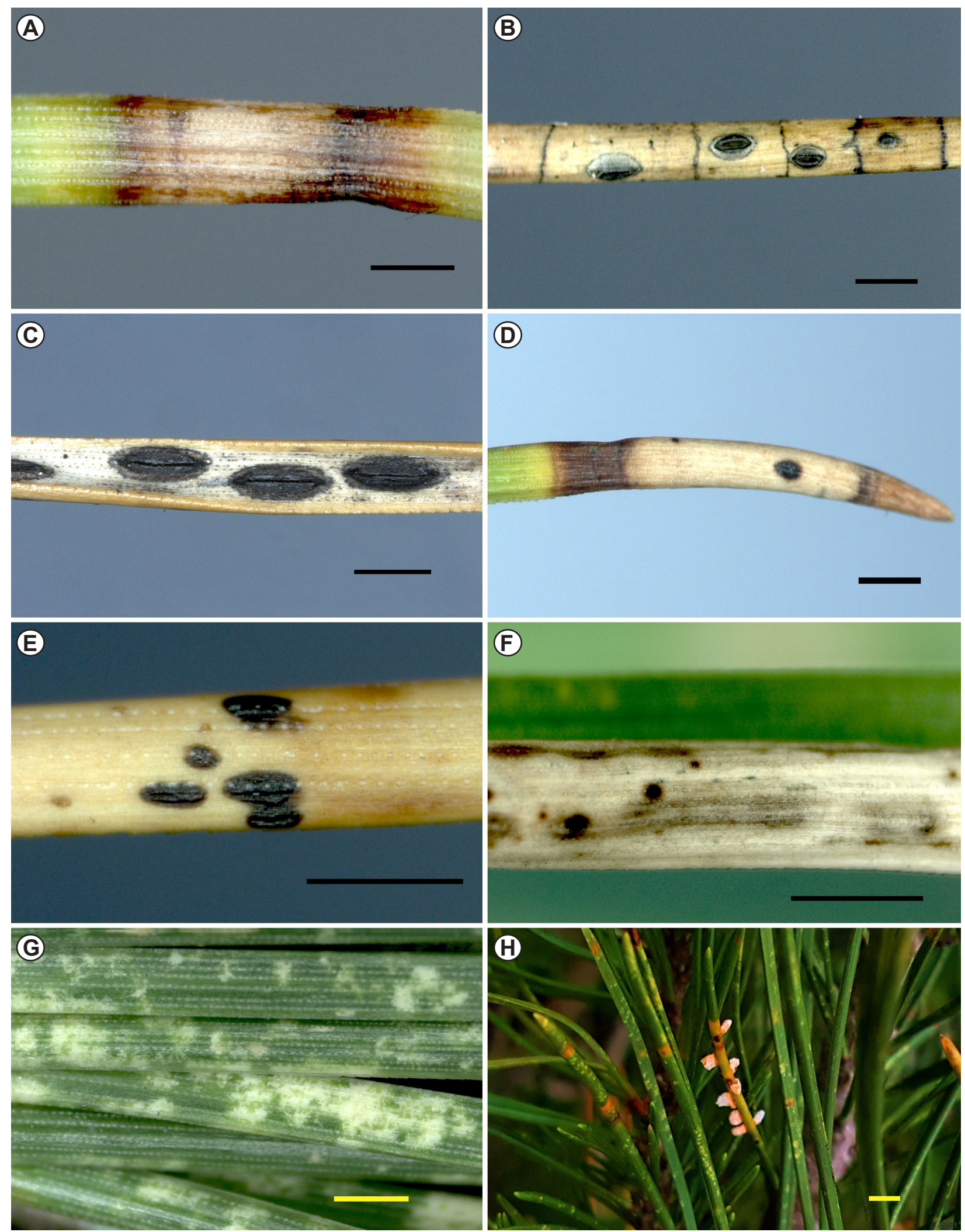

Figure 2. Etiological signs and symptoms of Pinus mugo needles: A - streaked necrosis (symptom type C); B - ascomata Lophodermium corconticum; C - ascomata Lophodermium conigenum; D - conidiomata Leptomelanconium allescheri; E - conidiomata and immature hysterothecia Lophodermium pini-mugonis; F - conidiomata Hendersonia sp.; G - needles with numerous irregular whitish yellow spots (type G symptoms); $\mathrm{H}-$ aecium Coleosporium senecionis (Photo A-G - T. Kowalski, Photo H - C. Bartnik). Scales: A-G $=2 \mathrm{~mm} ; \mathrm{H}=5 \mathrm{~mm}$. 
(ML), Maximum Parsimony (MP) and Bayesian inference $(\mathrm{BI})$.

Maximum likelihood (ML) analysis was run in PhyML 3.0 (Guindon et al. 2010) via the Montpelier online server (http://www.atgc-montpellier.fr/phyml/) with 1000 bootstrap replicates. The best evolutionary substitution model for the ITS region was $\mathrm{HKY}+\mathrm{G}$. The BI analysis was carried out in MrBayes v 3.1.2 (Ronquist \& Huelsenbeck 2003). The MCMC chains were run for 10 million generations using the best-fitted model. Trees were sampled every 100 generations, resulting in 100,000 trees from both runs. The burn-in value for each dataset was determined in Tracer v 1.4.1 (Rambaut \& Drummond 2007).

MP analyses were performed using PAUP* $4.0 \mathrm{~b} 10$ (Swofford 2003). Gaps were treated as fifth state. Bootstrap analysis (1000 bootstrap replicates) was conducted to determine the levels of confidence for the nodes within the inferred tree topologies. Tree bisection and reconnection (TBR) was selected as the branch swapping option. The tree length (TL), Consistency Index (CI), Retention Index (RI), Homoplasy Index (HI) and Rescaled Consistency Index (RC) were recorded for each analysed dataset after the trees were generated.

Estimates of average evolutionary divergence over sequence pairs within and between groups $L$. corconticum and $L$. conigenum were conducted using the Maximum Composite Likelihood model (Tamura et al. 2004). Codon positions included were $1 \mathrm{st}+2 \mathrm{nd}+3 \mathrm{rd}+$ Noncoding. All ambiguous positions were removed for each sequence pair (pairwise deletion option). Evolutionary analyses were conducted in MEGA X (Kumar et al. 2018).

\section{Results}

Fifty seven taxa were found in the needles of $P$. mugo, of which 33 were identified to species, 13 to genus, 2 to family, 3 to class and 6 were distinguished as unidentified (Table 3; Figs 2-3). Out of the seven types of disease symptoms identified on needles, the greatest species diversity of fungi was found in dead needles (29 taxa), and the smallest ( 5 taxa) in needles with symptoms of type $\mathrm{C}$ and $\mathrm{F}$ (Table 2). Fungi were most often isolated from needle fragments completely dead and living needles with necrosis progressing from the root (only 22.5\% and $21.1 \%$ of the fragments were sterile, respectively), and least frequently from needle fragments with $\mathrm{G}$ symptom (90.3\% sterile) and needles without disease symptoms (Table 2).

Much attention was paid to determining the species diversity of fungi from the genus Lophodermium. Comparison of the ITS sequences obtained from all representative isolates, initially assigned by their morphological characteristics to the genus Lophodermium, with sequences in GenBank database confirmed their genetic affinities among the different species of this genus. The isolates were distributed into three species. One isolate belonged to L. pini-mugonis, ten isolates belonged to L. conigenum and 33 isolates represented L. corconticum.

Based on the BLAST results, the currently obtained ITS sequences showed similarities ranging from $98.82 \%$ to $99.73 \%$ for $L$. conigenum, $98.20 \%$ to $100 \%$ for $L$. corconticum, and $100 \%$ for L. pini-mugonis when related to references sequences. The 44 complete ITS region sequences ranged in length from 538 to $716 \mathrm{bp}$. The shortest sequence belonged to L. pini-mugonis. The length of the $L$. conigenum sequence ranged from 690 to $705 \mathrm{bp}$. The longest sequences belonged to the L. corconticum sequence from (700-716 bp). The ITS sequences obtained from all isolates contain intron at the 3 ' end of $18 \mathrm{~S}$ subunit, except L. pini-mugonis. The intron length for L. conigenum ranged from 200 to $203 \mathrm{bp}$, and for L. corconticum from 2012 to $2014 \mathrm{bp}$. Alignments for the ITS dataset used in phylogenetic analyses contained 549 characters; including gaps.

The affiliation of the studied isolates to three known taxa, i.e., L. pini-mugonis, L. conigenum and L. corconticum, was also confirmed on the basis of ITS phylogenetic analyses (Fig. 4). The ITS sequences of these species form clades clearly distinguished from other species belonging to the genus Lophodermium. These clades are strongly supported by the results of analyses carried out with the use of ML and BI methods (Fig. 4). Evolutionary analyses involved 65 nucleotide sequences of $L$. corconticum and $L$. conigenum. There were a total of 549 positions

Table 2. Types of disease symptoms on needles and data on the isolation of fungi from needles.

\begin{tabular}{|c|c|c|c|c|c|}
\hline $\begin{array}{l}\text { Type of disease } \\
\text { symptoms }\end{array}$ & Characteristics of the symptom & $\begin{array}{l}\text { Number of } \\
\text { needles tested }\end{array}$ & $\begin{array}{l}\text { Number of } \\
\text { fragments }\end{array}$ & $\begin{array}{c}\text { Sterile } \\
\text { fragments } \\
(\%)\end{array}$ & $\begin{array}{l}\text { Number of isolated } \\
\text { fungal taxa }\end{array}$ \\
\hline A & Needles without symptoms & 50 & 240 & 77.5 & 12 \\
\hline B & $\begin{array}{l}\text { Needles with numerous yellow and yellow-brown } \\
\text { spots }\end{array}$ & 125 & 500 & 45.8 & 26 \\
\hline $\mathrm{C}$ & $\begin{array}{l}\text { Needles with a brown spot or streaked necrosis, } \\
\text { then associated with a dead top }\end{array}$ & 55 & 140 & 72.0 & 5 \\
\hline $\mathrm{D}$ & $\begin{array}{l}\text { Dead needles, only the living epiphyseal part } \\
(0.7-1.5 \mathrm{~cm} \text { long) remained }\end{array}$ & 75 & 190 & 41.2 & 24 \\
\hline $\mathrm{E}$ & Needles completely dead & 150 & 600 & 22.5 & 29 \\
\hline $\mathrm{F}$ & $\begin{array}{l}\text { Live needles, with necrosis progressing from } \\
\text { the base }\end{array}$ & 30 & 180 & 21.1 & 5 \\
\hline G & $\begin{array}{l}\text { Needles with numerous irregular whitish yellow } \\
\text { spots }\end{array}$ & 35 & 210 & 90.3 & 6 \\
\hline Total & & 520 & 2060 & & \\
\hline
\end{tabular}


Table 3. The species composition and the share of fungi inhabiting the needles of mountain pine with various symptoms. A-G - as in Table 2, $\mathrm{OE}$ - fungi were identified on the basis of their etiological signs; '+' - needles with etiological signs.

\begin{tabular}{|c|c|c|c|c|c|c|c|c|c|c|}
\hline \multirow[t]{2}{*}{ The name of the fungus } & \multirow{2}{*}{$\begin{array}{l}\text { Most similar } \\
\text { sequence in } \\
\text { GenBank }\end{array}$} & \multirow{2}{*}{$\begin{array}{l}\text { Similarity } \\
\quad(\%)\end{array}$} & \multicolumn{7}{|c|}{$\begin{array}{l}\text { The symptom type and } \% \text { of the inhabited needles } \\
\text { with this symptom }\end{array}$} & \multirow[t]{2}{*}{$\mathrm{OE}$} \\
\hline & & & A & $\mathrm{B}$ & $\mathrm{C}$ & $\mathrm{D}$ & $\mathrm{E}$ & $\mathrm{F}$ & G & \\
\hline Alternaria alternata (Fr.) Keissl & MH384939.1 & 100.0 & - & 1.6 & - & - & 5.3 & - & - & - \\
\hline $\begin{array}{l}\text { Alternaria caespitosa (de Hoog } \\
\text { \& C. Rubio) Woudenb. \& Crous }\end{array}$ & MH861255.1 & 99.5 & - & - & - & - & 1.3 & - & - & - \\
\hline Alternaria chartarum Preuss & MH430101.1 & 99.8 & - & - & - & - & 1.3 & - & - & - \\
\hline Alternaria infectoria E.G. Simmons & MK460954.1 & 99.5 & - & - & - & 17.1 & 4.0 & - & - & - \\
\hline Alternaria sp. & MG020276.1 & 99.4 & - & - & - & & 3.3 & - & - & - \\
\hline Alternaria tenuissima (Kunze) Wiltshire & MT573466.1 & 99.8 & & 2.4 & - & - & 4.0 & - & - & - \\
\hline $\begin{array}{l}\text { Aureobasidium pullulans (de Bary } \\
\text { \& Löwenthal) G. Arnaud }\end{array}$ & JX462671.1 & 99.0 & - & - & - & 5.7 & 2.0 & - & - & - \\
\hline Basidiomycetes & GU566227.1 & 98.0 & - & - & - & 1.4 & - & - & 2.9 & - \\
\hline Biscogniauxia nummularia (Bull.) Kuntze & MH860015.1 & 99.3 & 4.0 & - & - & 2.9 & - & 3.3 & 2.9 & - \\
\hline Botrytis cinerea Pers. & KP050616.1 & 100.0 & - & 1.6 & - & - & - & - & - & - \\
\hline Cadophora sp. & JF327416.1 & 99.0 & - & 2.4 & - & - & - & - & - & - \\
\hline Cenangium acuum Cooke \& Peck & LT158445.1 & 98.2 & - & 3.2 & - & 4.3 & - & - & - & - \\
\hline Cenangium ferruginosum Fr. & LT158467.1 & 100.0 & 2.0 & 3.2 & - & - & - & 3.3 & 2.9 & - \\
\hline $\begin{array}{l}\text { Cladosporium allicinum (Fr.) Bensch, } \\
\text { U. Braun \& Crous }\end{array}$ & KP701895.1 & 100.0 & - & 0.8 & - & - & - & - & - & - \\
\hline $\begin{array}{l}\text { Cladosporium cladosporioides (Fresen.) } \\
\text { G.A. de Vries }\end{array}$ & KU314943.1 & 99.0 & 4.0 & 4.0 & - & 2.9 & 4.0 & - & - & - \\
\hline Cladosporium cucumerinum Ellis \& Arthur & KF156302.1 & 100.0 & - & - & - & - & 1.3 & - & - & - \\
\hline Cladosporium herbarum (Pers.) Link & LN808882.1 & 99.8 & - & 0.8 & 3.6 & - & 0.7 & - & - & - \\
\hline $\begin{array}{l}\text { Cladosporium sinuosum K. Schub., } \\
\text { C.F. Hill, Crous \& U. Braun }\end{array}$ & MH863128.1 & 100.0 & - & - & - & - & 1.3 & - & - & - \\
\hline Cladosporium sp. & KT898724.1 & 100.0 & - & - & - & 7.1 & 5.3 & - & - & - \\
\hline $\begin{array}{l}\text { Coleosporium senecionis (Schumach.) } \\
\text { Rabenh. }\end{array}$ & KY810472.1 & 99.4 & - & - & - & - & - & - & - & + \\
\hline Coniochaeta sp. & JN225913.1 & 99.2 & - & - & - & - & 1.3 & - & - & - \\
\hline Davidiella sp. & KP714607.1 & 99.0 & - & - & - & 2.9 & & - & - & - \\
\hline Desmazierella acicola Lib. & MT790315.1 & 99.3 & 6.0 & & & 5.7 & 0.7 & - & - & - \\
\hline $\begin{array}{l}\text { Dinemasporium sasae A. Hashim., Sat. } \\
\text { Hatak. \& Kaz. Tanaka }\end{array}$ & NR_155038.1 & 99.3 & - & - & - & 2.9 & - & - & - & - \\
\hline Dothideomycetes & KY436101.1 & 99.8 & - & - & - & 4.3 & - & - & - & - \\
\hline Epicoccum nigrum Link & MH861752.1 & 99.6 & 4.0 & 1.6 & & 4.3 & - & - & - & - \\
\hline $\begin{array}{l}\text { Fimetariella rabenhorstii (Niessl) } \\
\quad \text { N. Lundq. }\end{array}$ & JX421715.1 & 100.0 & 2.0 & 0.8 & - & - & 0.7 & - & - & - \\
\hline Hendersonia sp. & KT000192.1 & 99.8 & 2.0 & 9.6 & - & 7.1 & 46.5 & 3.3 & & + \\
\hline Herpotrichia sp. & KT581851.1 & 98.0 & - & - & - & - & 2.0 & - & - & - \\
\hline Hormonema sp. & KP714567.1 & 100.0 & - & - & - & - & 2.7 & - & - & - \\
\hline Lachnellula calyciformis (Batsch) Dharne & MH858771.1 & 99.8 & - & - & - & 2.9 & - & - & - & - \\
\hline Lachnellula subtilissima (Cooke) Dennis & MH752069.1 & 98.6 & - & - & - & 2.9 & - & - & - & - \\
\hline Leotiomycetes sp. & KP990974.1 & 99.8 & - & - & - & 4.3 & - & - & - & - \\
\hline $\begin{array}{l}\text { Leptomelanconium allescheri (Schnabl) } \\
\quad \text { Petr. }\end{array}$ & MF573935.1 & 98.0 & 6.0 & 0.8 & 2.0 & 1.4 & 5.3 & - & - & + \\
\hline Lopadostoma turqidum (Pers.) Traverso & KC774617.1 & 100.0 & 2.0 & - & - & - & - & - & - & - \\
\hline $\begin{array}{l}\text { Lophodermium conigenum (Brunaud) } \\
\text { Hilitzer }\end{array}$ & KY742578.1 & 99.6 & 12.0 & 17.6 & 12.7 & 7.1 & 17.3 & 3.3 & 5.7 & + \\
\hline $\begin{array}{l}\text { Lophodermium corconticum Koukol, Pusz } \\
\text { \& Minter }\end{array}$ & HG939564.1 & 99.4 & 4.0 & 32.0 & 21.8 & 12.9 & 14.0 & - & 2.9 & + \\
\hline $\begin{array}{l}\text { Lophodermium pini-mugonis C.L. Hou } \\
\text { \& M. Piepenbr. }\end{array}$ & JF332165.1 & 100.0 & - & - & - & - & 0.7 & - & - & + \\
\hline Massarinaceae & KJ486534.1 & 99.4 & - & - & - & - & 1.3 & - & - & - \\
\hline Mollisia sp. & MH860088.1 & 95.2 & - & - & - & - & 1.3 & - & - & - \\
\hline $\begin{array}{l}\text { Mycosphaerella tassiana (De Not.) } \\
\text { Johanson }\end{array}$ & HG935310.1 & 99.0 & - & - & - & 4.3 & - & - & - & - \\
\hline Nemania serpens (Pers.) Gray & KU141386.1 & 99.0 & 4.0 & - & - & - & 1.3 & - & - & - \\
\hline $\begin{array}{l}\text { Parastagonospora avenae (A.B. Frank) } \\
\text { Quaedvl., Verkley \& Crous }\end{array}$ & LT603040.1 & 99.6 & - & 2.4 & - & - & - & - & - & - \\
\hline $\begin{array}{l}\text { Periconia macrospinosa Lefebvre } \\
\quad \& \text { Aar.G. Johnson }\end{array}$ & MN547378.1 & 99.4 & - & - & - & 4.3 & - & - & - & - \\
\hline
\end{tabular}


Table 3. Continued.

\begin{tabular}{|c|c|c|c|c|c|c|c|c|c|c|}
\hline \multirow[t]{2}{*}{ The name of the fungus } & \multirow{2}{*}{$\begin{array}{l}\text { Most similar } \\
\text { sequence in } \\
\text { GenBank }\end{array}$} & \multirow{2}{*}{$\begin{array}{l}\text { Similarity } \\
\quad(\%)\end{array}$} & \multicolumn{7}{|c|}{$\begin{array}{l}\text { The symptom type and \% of the inhabited needles } \\
\text { with this symptom }\end{array}$} & \multirow[t]{2}{*}{$\mathrm{OE}$} \\
\hline & & & $\mathrm{A}$ & B & $\mathrm{C}$ & $\mathrm{D}$ & $\mathrm{E}$ & $\mathrm{F}$ & G & \\
\hline Pezizomycetes & GQ153137.1 & 99.0 & - & 1.6 & - & - & - & - & - & - \\
\hline Phaeosphaeria sp. & EF432300.1 & 99.6 & - & 3.2 & - & - & - & - & - & - \\
\hline Phialocephala sp. & FR774054.1 & 99.8 & - & 1.6 & - & 1.4 & - & - & - & - \\
\hline Rhytismataceae & KF889704.1 & 96.0 & - & - & - & 1.4 & 0.7 & - & - & + \\
\hline $\begin{array}{l}\text { Sydowia polyspora (Bref. \& Tavel) } \\
\text { E. Müll. }\end{array}$ & JN944640.1 & 100.0 & - & 1.4 & 7.3 & 7.1 & 0.7 & 56.7 & 2.9 & - \\
\hline Trichoderma lixii (Pat.) P. Chaverri & KU934235.1 & 99.0 & - & - & - & - & 2.0 & - & - & - \\
\hline Xylaria sp. Pm 61 & KP174691.1 & 98.0 & - & 0.8 & - & - & - & - & - & - \\
\hline Unidentified Pm 32 & - & - & - & - & - & - & 2.0 & - & - & - \\
\hline Unidentified Pm 49 & - & - & - & 0.8 & - & - & - & - & - & - \\
\hline Unidentified Pm 50 & - & - & - & 2.4 & - & - & - & - & - & - \\
\hline Unidentified Pm 52 & - & - & - & 0.8 & - & - & - & - & - & - \\
\hline Unidentified Pm 62 & - & - & - & 0.8 & - & - & - & - & - & - \\
\hline Unidentified Pm 67 & - & - & - & 0.8 & - & - & - & - & - & - \\
\hline
\end{tabular}

in the final dataset (Table 4). The L. corconticum groups, which consisted of 33 sequences, indicated some variation. Subpopulations of $L$. corconticum represented by groups 1 and $1 \mathrm{R}$ indicated low within-group (respectively $0.0052,0.0054)$ and between-group (0.0052) divergences. It can therefore be concluded that the sequences of L. corconticum obtained in the present study do not differ significantly from reference sequences deposited in GenBank. The differences between the groups representing L. corconticum and L. conigenum ranged from 0.0646 to 0.0798 . The L conigenum groups, which consisted of 10 sequences, indicated substantial variation. Subpopulations of $L$. conigenum represented by groups $2,2 \mathrm{R}-\mathrm{a}$ and $2 \mathrm{R}-\mathrm{b}$ indicated low divergences within-group (from 0.0014, to 0.0050). Divergences between-group for subpopulations represented by groups 2 and 2R-a were low (0.0031).

Table 4. Estimates of average evolutionary divergence over sequence pairs within (d) and between groups* $(D)$.

\begin{tabular}{l|c|c|c|c|c}
\hline $\mathrm{D}^{* *}$ & $\begin{array}{c}\text { Group } \\
1\end{array}$ & $\begin{array}{c}\text { Group } \\
1 \mathrm{R}\end{array}$ & $\begin{array}{c}\text { Group } \\
2\end{array}$ & $\begin{array}{c}\text { Group } \\
\text { 2R-a }\end{array}$ & $\begin{array}{c}\text { Group } \\
\text { 2R-b }\end{array}$ \\
\hline Group 1 & - & 0.0052 & 0.0647 & 0.0654 & 0.0798 \\
Group 1R & 0.0052 & - & 0.0646 & 0.0653 & 0.0796 \\
Group 2 & 0.0647 & 0.0646 & - & 0.0031 & 0.0386 \\
Group 2R-a & 0.0654 & 0.0653 & 0.0031 & - & 0.0399 \\
Group 2R-b & 0.0798 & 0.0796 & 0.0386 & 0.0399 & - \\
$\mathrm{d}^{* * *}$ & 0.0052 & 0.0054 & 0.0016 & 0.0050 & 0.0014 \\
\hline
\end{tabular}

* Groups: 1 - sequences of Lophodermium corconticum obtained in this study; 1R - references sequences of Lophodermium corconticum obtained from GenBank. 2 - sequences of Lophodermium conigenum obtained in this study; 2R-a - references sequences of Lophodermium conigenum obtained from GenBank, which formed the same lineage with the sequences obtained in this study on the phylogram (Fig. 4); $2 \mathrm{R}-\mathrm{b}$ - references sequences of Lophodermium conigenum obtained from GenBank, which formed the sister lineage related to the sequences obtained in this study on the phylogram (Fig. 4).

** The number of base substitutions per site from averaging overall sequence pairs between groups are shown.

*** The number of base substitutions per site from averaging overall sequence pairs within each group are shown.
Therefore, it can be concluded that this is the level of nucleotide differences corresponding to intraspecific variations. Divergences between-group for subpopulations represented by groups 2 , and $2 \mathrm{R}$-a vs $2 \mathrm{R}-\mathrm{b}$ were relatively high (respectively 0.0386 and 0.0399 ). This result indicates a high probability that the sequence group $2 \mathrm{R}-\mathrm{b}$ represents a species other than L. conigenum (Table 4). It was also confirmed on the basis of ITS phylogenetic analyses which revealed that sequences of $L$. conigenum obtained from GenBank formed strongly supported sister lineage with some of the sequences obtained in this study on the phylogram (Fig. 4).

Twelve taxa were isolated from needles without disease symptoms, of which 10 were also found in needles with various disease symptoms. These included primarily: L. conigenum, L. corconticum, Desmazierella acicola and Leptomelanconium allescheri. The frequency of isolation of these fungi from needles without symptoms ranged from $6.0 \%$ for Lep. allescheri up to $12.0 \%$ for L. conigenum.

Among the identified fungi, the needles were colonized by four species with a high frequency: Lophodermium corconticum, L. conigenum, Sydowia polyspora and Hendersonia $\mathrm{sp}$. The L. corconticum was isolated from the 6 types of needles tested (except type F). The most numerous were on type B $(32.0 \%)$ and type C $(21.8 \%)$ (Fig. 2A). On dead needles, this fungus produced the characteristic ascomata, conidiomata and black lines (Fig. 2B). In vitro, developed a white colony with black sclerotic mycelium in the form of patches or lines and colorless, bacilliform conidia (Fig. 3A-B). L. conigenum inhabited all types of needles, and was most often isolated from needles type B (17.6\%) and type E (17.3\%). On the dead needles, this fungus produced ascocarps, conidiomata and sometimes brown fuzzy oblique stripes (Fig. 2C). On the other hand, on the MEA medium, it produced colonies with sparse air mycelium, white-cream to light brown in color, and rod-shaped conidia (Fig. 3G-H).

Sydowia polyspora was isolated from most types of symptoms (except type A), but most often this fungus 
inhabited live needles, with necrosis progressing from the root $(56.7 \%)$.

Hendersonia sp. was isolated from 5 types of needles, most often from dead needles $(46.5 \%)$ and needles with yellow and yellow-brown spots, and from needles with
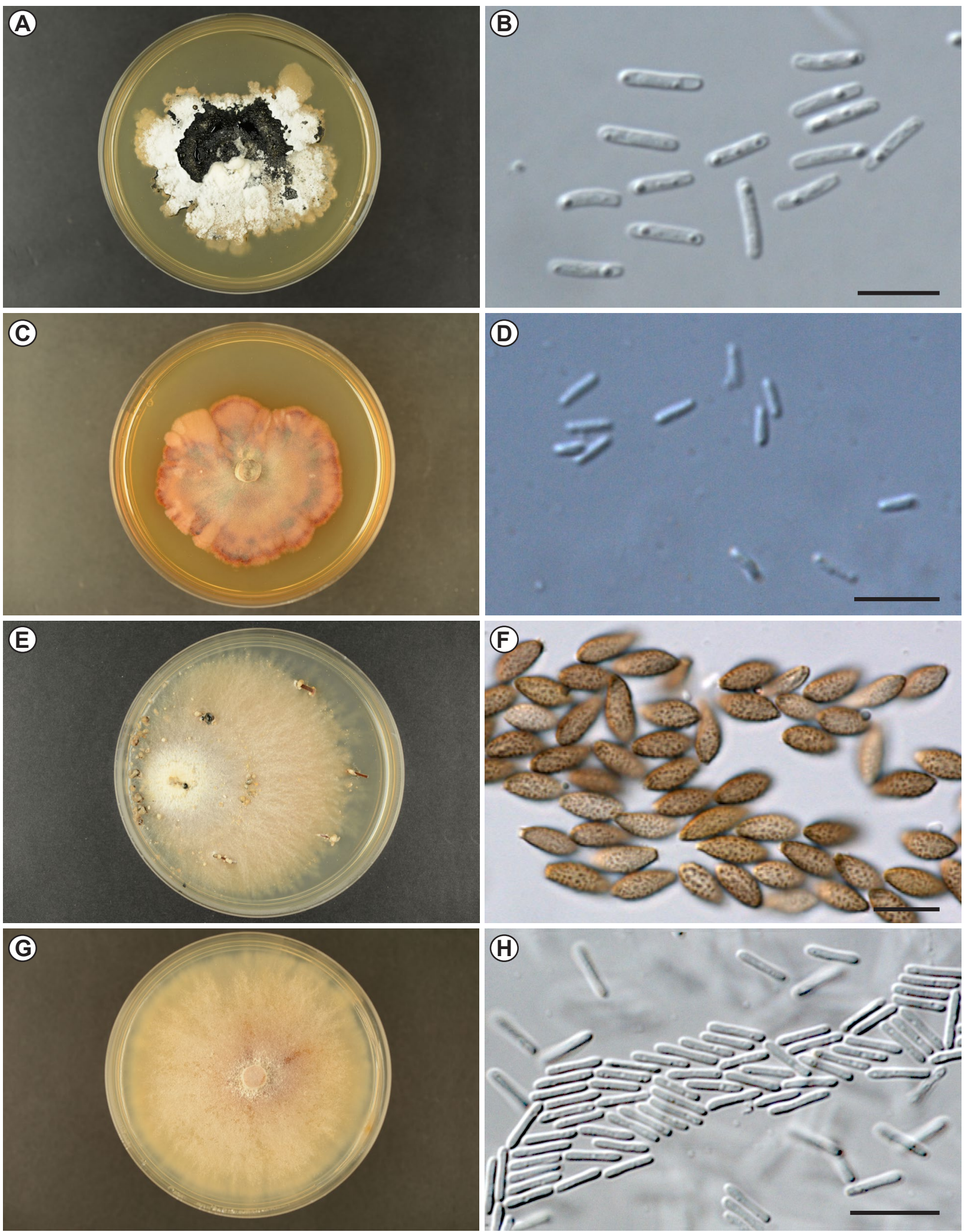

Figure 3. Cultures of fungi isolated from the Pinus mugo needles: A - culture Lophodermium corconticum (no. 381KS); B - conidia Lophodermium corconticum; C - culture Lophodermium pini-mugonis; D - conidia Lophodermium pini-mugonis (no. 445KS); E - culture Leptomelanconium allescheri (no. Pm68KS); F - macroconidia Leptomelanconium allescheri; G - culture Lophodermium conigenum (no. 386KS); H - conidia

Lophodermium conigenum (Photo T. Kowalski). Scales: B, F, H $=10 \mu \mathrm{m}$; D $=5 \mu \mathrm{m}$.

a viable epiphyseal part only $(9.6 \%$ and $7.1 \%$, respectively). This fungus produced black pycnidial conidiomata on dead needles (Fig. 2F).

The group of fungi with a lower frequency of occurrence and usually isolated from 2 or 3 (occasionally 4-5)
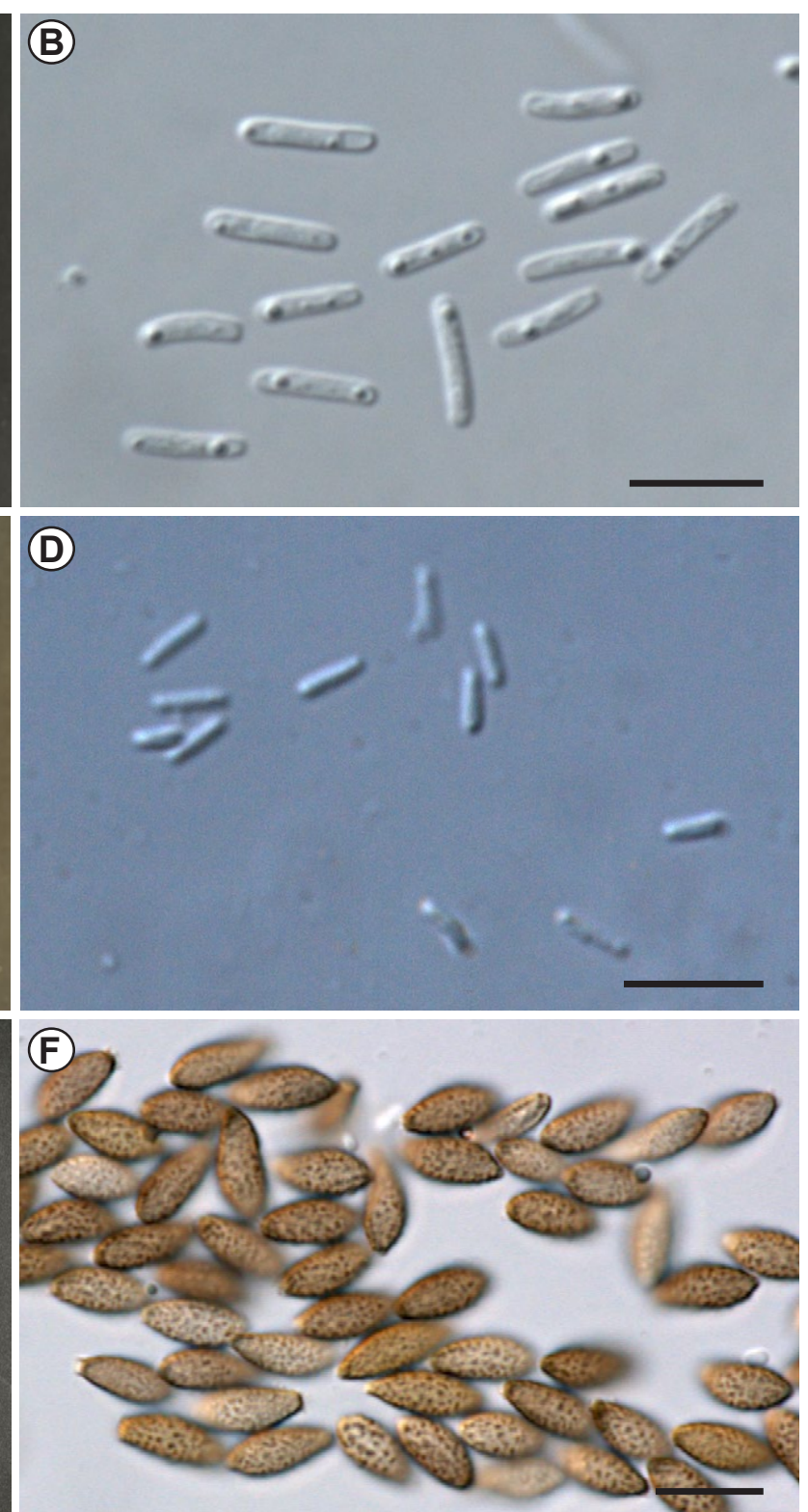


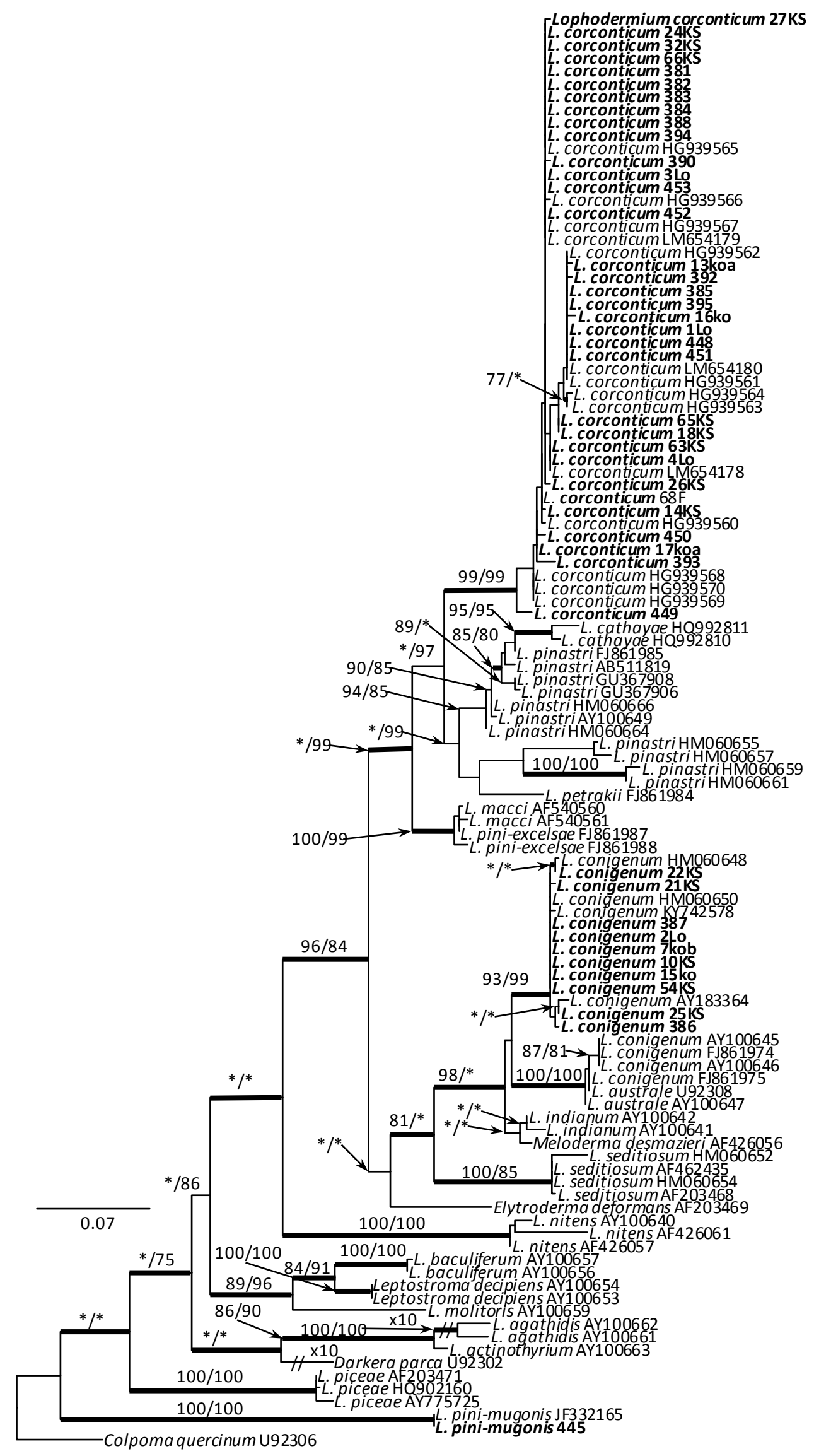

Figure 4. Phylogram obtained from Maximum Likelihood (ML) analyses of the ITS data for the isolated fungal taxa belonged to Lophodermium genus. Sequences obtained during this study are presented in bold type. The Bootstrap values $\geq 75 \%$ for ML and Maximum Parsimony (MP) analyses are presented at nodes as follows: ML/MP. Bold branches indicate posterior probabilities values $\geq 0.95$ obtained from Bayesian Inference (BI) analyses. * Bootstrap values $<75 \%$. The tree is drawn to scale (see bar) with branch length measured in the number of substitutions per site. Colpoma quercinum represent the outgroup. 
types of symptoms included 18 taxa: Alternaria infectoria, Biscogniauxia nummularia, Cladosporium spp., Desmazierella acicola, Leptomelanconium allescheri, Cenangium ferruginosum, Nemania serpens, Alternaria spp., Cenangium acuum and one taxon from the Rhytismataceae family. The frequency of their occurrence depending on the type of disease symptom is given in Table 3. Some of them produced etiological signs on the needles in situ. Lep. allescheri produced black acervular conidiomata (Fig. 2D) on dead and dying needles, and on MEA medium it developed colonies yellowish-olive to yellowish brown, with weak aerial mycelium, sometimes with visible black tar drops (macroconidia) (Fig. 3E-F). An unidentified species of the fungus from the Rhytismataceae family also produced hysterothecia with club-shaped, mucus-surrounded ascospores on dead parts of needles. Very limited growth on MEA medium was observed for this species, both from ascospores and from fragments of infested needles, which made identification difficult. In the case of Lophodermium pini-mugonis, immature ascomata and conidiomata were found on a dead attached needle in autumn (Fig. 2E), containing hyaline, rod shaped, $2-3.5 \times 0.8-1.2 \mu \mathrm{m}$ conidia (Fig. 3D). After four weeks on the MEA medium, the colony reached a diameter of $60-80 \mathrm{~mm}$ at $20^{\circ} \mathrm{C}$. It is compact, adherent to the nutrient solution, with a modest air suede mycelium, cream-orange to orange-brown, sometimes with darker zones (Fig. 3C). The frequency of the obligate parasite, Coleosporium senecionis, was determined by the ecium stage on the needles (Fig. 2H). The presence of this species was found on $3.3 \%$ of the needles (Table 3 ). This fungus is responsible for the pine blister rust.

Most taxa (61.4\%) were isolated from only one type of symptom (B, D or E), and their frequency of occurrence was relatively low and ranged from 0.7 to $4.3 \%$ (average $2.1 \%$ ) of the inhabited needles. There are two known pathogenic species in the group of these fungi: Botrytis cinerea and Herpotrichia sp. (Table 3).

Needles with numerous irregular whitish yellow spots (Fig. 2G) were only sporadically populated by fungi. Only six species of fungi were isolated from $9.7 \%$ of needle fragments. The frequency of their occurrence did not exceed $3 \%$, with the exception of L. conigenum (5.7\%).

\section{Discussion}

The obtained results indicate a large diversity of disease symptoms on the needles of $P$. mugo and a significant diversity of species of fungi present in such needles. One of the symptoms on P. mugo needles was whitish-yellow spots (Type G). From such needles, it was possible to isolate fungi only sporadically, which suggests that their cause should be seen among the abiotic factors. The occurrence of similar spots on P. mugo and with a particularly high frequency on Picea abies is reported by Schütt et al. (1985). In the case of P. abies, such discoloration intensified with the increase of altitude above sea level in mountainous areas. There were numerous indications that they could be caused by photo-oxidants (Lang \& Holdenrieder 1985; Schütt et al. 1985). Evidence for potential impacts of ozone was also observed at some mountain sites in Europe on Pinus cembra (Wieser et al. 2005) and on other conifers in mountain forest stands in California (Bytnerowicz et al. 2008).

When considering the role of the identified species of fungi, it should be borne in mind that the assimilation apparatus of forest trees is commonly inhabited by endophytic fungi that live inside plant cells for a significant period of their life cycle without causing visible disease symptoms (Sieber 2007). The colonization frequency and species diversity of endophytic fungal communities are affected by host species, tissue age and geographic location (Saikkonen et al. 1998; Sieber 2007). The endophyte communities in angiosperms are frequently dominated by species of Diaporthales and those in gymnosperms by species of Helotiales (Sieber 2007). In Poland, over 80 taxa of fungi have been found in the symptomless needles of $P$. sylvestris and 40 taxa in the needles of $P$. nigra (Kowalski 1993; Kowalski \& Zych 2002). In P. mugo needles, the endophytic fungal community seems to be significantly poorer. Sieber et al. (1999) in symptomless needles of P. mugo ssp. uncinata in Switzerland found 11 species. In the current research in the Tatra Mountains, 12 species have been isolated from such needles. It is important to know the species composition of endophytes because some of them are, however, opportunistic and can cause disease after the host has been weakened by some other factor (Sieber 2007). This is one of the important, difficult to resolve the problems, which endophytes contribute to the disease of plant organs, and which, taking advantage of their death for other reasons, produce their fruiting bodies on them. This problem was highlighted in Germany in relation to the common premature browning disease and spruce needle fall (Butin 1986). This aspect should also be considered when analyzing the role of fungi as the cause of $P$. mugo needle disease in the Tatra Mountains. Among the endophytes we found, there are those found also on $P$. mugo and other pine species in other regions of the world. A typical representative of this group is Cenangium ferruginosum (Hata \& Futai 1995; Sieber et al. 1999). In turn, Desmazierella acicola is a common endophyte in the needles of $P$. sylvestris and P. nigra in Poland (Kowalski 1993; Kowalski \& Zych 2002), which then occurs on fallen needles in the litter as a saprotroph (Kowalski 1988). In contrast, representatives of the genera Alternaria, Cladosporium and Epicoccum are isolated as endophytes from a wide range of conifers and deciduous plants.

P. mugo needles in the Tatra Mountains showed very diverse types of discoloration during the study period, sometimes preceded by distinct tissue necrosis. The discoloration of more than 40 taxa of fungi in needles with various types of discoloration indicates a large species diversity of fungi able to colonize the tissues of $P$. mugo needles. The only representative of the obligate parasites was Coleosporium senecionis, which produced the aecium stage on living needles. The remaining species, in terms of trophic conditions, should be classified as relative parasites or saprotrophs, secondarily inhabiting dying tissues. Some species found in symptomatic needles may have existed previously in needles as endophytes, confirming 
the views expressed by other authors (Saikkonen et al. 1998; Sieber et al. 1999; Sieber 2007).

The fungi known for frequent colonization of the needles of Pinus spp. include numerous species of the genus Lophodermium, with different ability to cause disease symptoms (Minter \& Millar 1980; Kowalski 1982; OrtizGarcía et al. 2003; Salas-Lizana \& Oono 2018). On P. sylvestris in Europe, L. pinastri and L. seditiosum and locally L. conigenum are most often recorded (Minter \& Millar 1980; Reignoux et al. 2014), and also L. pini-excelsae, which occurs mainly in 5-needle pines (Minter et al. 1978). Among these species, only L. seditiosum shows clear pathogenic character on $P$. sylvestris, and $L$. conigenum inhabits mainly trash needles. Lophodermium pinastri fructifies mainly on fallen needles in the litter (Minter \& Millar 1980), but it is also a common endophyte. Reignoux et al. (2014) drew attention to the significant differentiation of L. pinastri endophytically occurring in living needles, distinguishing three cryptic taxa within it. In Poland, only L. pinastri and L. seditiosum were found in P. sylvestris nurseries and stands, and their occurrence depended on the age of the stand and the age of the needles (Kowalski 1982, 1988, 1993). According to Butin (1984), in Germany, there are mainly three Lophodermium species on P. nigra, with L. conigenum, L. pinastri inhabiting mainly dead or dying needles, while sometimes only L. seditiosum has phytopathogenic significance.

In the current research, three species of Lophodermium were found on the needles of P. mugo: L. conigenum, L. corconticum and L. pini-mugonis. Of these, only L. conigenum is more widely known from various pine species in many regions of Europe (Minter et al. 1978; Minter \& Millar 1980; Butin 1984; Koukol et al. 2015). While on P. sylvestris and P. nigra it is treated more like a saprotroph, whereas, on $P$. mugo it was often found as an endophyte. It was also isolated from symptomatic needles and then its fructification was observed on dead needles. L. corconticum was described on the needles of P. mugo from the Karkonosze Mountains in Poland (Koukol et al. 2015) and so far it has not been recorded outside of this region. The Polish Tatras are therefore the second recognized site for this species. Its finding on needles showing various symptoms of necrosis and discoloration may suggest that it exhibits some pathogenic properties, while its presence in living symptomless needles may indicate that it is capable of living as an endophyte. However, it should be noted that after a successful infection, pathogenic fungi begin the incubation period, after which disease symptoms appear. To obtain a credible answer in this regard, it will be necessary to carry out pathogenicity tests. As Koukol et al. (2015) already indicated, L. concorticum produces hysterothecia, conidiomata and black lines on the needles, very similar to those produced by $L$. pinastri. The in vitro colonies are also similar (Kowalski 1982). Therefore, it cannot be ruled out that $L$. concorticum also occurs in other regions of Europe on P. mugo, but can be treated as L. pinastri sensu lata. In the present research, L. pinastri has not been found.

Recently, a new species of L. pini-mugonis was described on the needles of P. mugo in the German Alps
(Hou et al. 2009). Until now, this species is only known from the type collection. During the current research in the Polish Tatras, its presence was confirmed on one needle. Despite good genetic compatibility with the holotype, there are some differences in the microscopic features of conidia. The conidia we observed in conidiomata in situ were slightly longer and rather rod shaped or cylindrical, quite typical in shape to many other Lophodermium spp. (Minter 1981). They were significantly shorter than those of L. conigenum or many other Lophodermium spp. (Minter 1981). Hou et al. (2009) specify that the conidia were ellipsoidal in shape. In the present work, a colony of this species in vitro is also presented for the first time. To determine the degree of variability within fruiting body and in vitro colonies, it would be necessary to find a larger number of needles colonized by this species.

Summing up the aspect of the presence of Lophodermium spp. on $P$. mugo in the Polish Tatras, it should be stated that it is significantly different from the species composition of Lophodermium fungi occurring in Poland on P. sylvestris (Kowalski 1982, 1988, 1993).

Currently conducted research has provided numerous data on Lophodermium at the molecular level. Koukol et al. (2015) describing L. corconticum demonstrated the ability to identify isolates of the species based on the analysis of the ITS, which was also confirmed in the present work. Unfortunately, these authors have deposited the sequences with GenBank without describing the ITS regions. This is of particular importance for the appropriate preparation of data for phylogenetic analysis and for ensuring the comparability of the results with other studies. In this work, as in the publication by Ortiz-García et al. (2003), fragments of the ITS sequence containing the intron were excluded from the phylogenetic analysis. All L. corconticum sequences obtained in this study contained an intron within the 18S fragment. Comparing them with the reference sequences obtained by Koukol et al. (2015), it can be concluded that the intron was present in all sequences except one, the length of which did not allow the assessment of the presence of the intron. Common, but not mandatory presence of an intron sequence in the region of $18 \mathrm{~S}$ fungi of the genus Lophodermium was pointed by Ortiz-García et al. (2003), and confirmed in this study. There was no intron in the ITS sequence of Lophodermium pini-mugonis, while the L. corconticum and L. conigenum sequences had introns of different lengths. The length of these introns, however, did not exceed that reported by Ortiz-García et al. (2003) of 225 bp. According to Ortiz-García et al. (2003) species of the genus Lophodermium differ in the level of intraspecific variation in the ITS sequence. For example, the differences between the sequences obtained from isolates were for: L. pinastri $5.6 \%$, L. agathidis $2.9 \%$ and L. conigenum $0 \%$. Koukol et al. (2015) reported that the nucleotide variation in ITS sequences for L. corconticum does not exceed $0.5 \%$, which was also confirmed by the results of this study. The subpopulation of L. corconticum from the Tatra Mountains does not differ in terms of ITS sequence from the subpopulation from the Sudetes. This is also confirmed by the lack of lineage in the phylogram 
(Fig. 2) representing the geographical variation of ITS sequences for this species.

The result of the phylogenetic analysis shows that the ITS sequences obtained from the isolates of fungi designated as $L$. conigenum do not form one clade. There are two sister clades in Fig. 2. A similar system of relations between $L$. conigenum isolates was also found by Koukol et al. (2015). L. conigenum sequences obtained in the present study from isolates derived from $P$. mugo needles form one clade with sequences of fungi isolated from $P$. sylvestris in Scotland, most of which come from studies by Reignoux et al. (2014). The second clade includes sequences of fungi designated as L. conigenum and L. australe. Among this group of sequences, a separate lineage is formed by sequences obtained from L. conigenum, for which the host plants were Pinus radiata from New Zealand and $P$. thunbergii from China. Large differences between $L$. conigenum sequences were also presented in the phylogram by Wang et al. (2010). Such a system of relations between $L$. conigenum sequences from different geographic regions and obtained from different host plants may indicate incorrect identification of isolates or the existence of cryptic species.

Kowalski et al. (2018) found the fungus Leptomelanconium allescheri in the Polish Tatras for the first time. The present study has provided further data on the occurrence of this fungus species on $P$. mugo, in particular its relationship to the characteristic necrotic areas and the discoloration of the needles and the dieback of their tops, suggesting its pathogenic abilities. The teleomorphic stage of this species has still not been found. The finding of Sclerophoma pythiophila fungus in the needles of $P$. mugo dying from the base should be considered a new aspect. This type of dieback is typical in situations where there is a previous necrosis of the shoots. In general, Gremmeniella abietina or Cenangium ferruginosum is isolated from such dying bases of needles of other Pinus species (Kowalski \& Domański 1983). In this regard, it would be advisable to extend the research to include fungi causing $P$. mugo shoot dieback. Further taxonomic research require some fungi currently distinguished only to the genus or family in order to identify them properly, and then they should link with the observed disease symptoms. Moreover, it should be emphasized that, despite detailed studies, no presence of pathogens dangerous in other regions, such as Dothistroma septosporum, D. pini or Mycosphaerella dearnessii, was found by either etiological signs or among isolated cultures (Pehl \& Butin 1992; Holdenrieder \& Sieber 1995; Pehl 1995; La Porta \& Capretti 2000; Barnes et al. 2011; Boroń et al. 2016).

\section{Acknowledgements}

The research was co-financed by the forest fund grant provided by the State Forests to the Tatra National Park in 2020.

\section{References}

Andjelič, M. 2000. Disease of the mountain pine (Pinus mugo Turra) in the area of 'Lovcen' National Park (Montenegro, Yugoslavia). Zastita prirode 52(1): 69-78.
Ballian, D., Ravazzi, C., de Rigo, D. \& Caudullo, G. 2016. Pinus mugo in Europe: Distribution, habitat, usage and threats. In: San-Miguel-Ayanz, J., de Rigo, D., Caudullo, G., Houston Durrant T. \& Mauri, A. (eds), European Atlas of Forest Tree Species, pp. 124-125. Luxembourg: Publication Office of the European Union.

Barnes, I., Kirisits, T., Wingfield, M. J. \& Wingfield, B. D. 2011. Needle blight of pine caused by two species of Dothistroma in Hungary. Forest Pathology 41: 361-369. https://doi.org/10.1111/j.14390329.2010.00689.x

Bednářová, M., Palovčíková, D. \& Jankovský, L. 2006. The host spectrum of Dothistroma needle blight Mycosphaerella pini E. Rostrup - new hosts of Dothistroma needle blight observed in the Czech Republic. Journal of Forest Science 52(1): 30-36. https:// doi.org/10.17221/4484-jfs

Boratyńska, K. 2002. Needle variability of Pinus mugo Turra in the West Tatra Mts. Dendrobiology 48: 3-8.

Boratyńska, K., Marcysiak, K. \& Boratyński A. 2005. Pinus mugo (Pinaceae) in the Abruzzi Mountains: high morphological variation in isolated populations. Botanical Journal of the Linnean Society 147: 309-316. https://doi.org/10.1111/j.1095-8339.2005.00374.x

Boroń, P., Lenart-Boroń, A. \& Mullett, M. 2016. The distribution of Dothistroma septosporum and its mating types in Poland. Forest Pathology 46: 489-496. https://doi.org/10.1111/efp.12262

Butin, H. 1984. Pilzkrankheiten der Schwarzkiefer. Allgemeine Forstzeitschrift 23: 585-587.

Butin, H. 1986. Endophytic fungi in green needles of Norway spruce (Picea abies Karst). Zeitschrift fuer Mykologie 52(2): 335-346.

Bytnerowicz, A., Arbaugh, M., Schilling, S., Fraczek, W. \& Alexander, D. 2008. Ozone distribution and phytotoxic potential in mixed conifer forests of the San Bernardino Mountains, southern California. Environ Pollution 155(3): 398-408. https://doi.org/10.1016/j. envpol.2008.01.046

Darriba, D., Taboada, G. L., Doallo, R. \& Posada, D. 2012. jModelTest 2: more models, new heuristics and parallel computing. Nature Methods 9: 772. https://doi.org/10.1038/nmeth.2109

Giordano, L. \& Gonthier, P. 2011. An outbreak of Cyclaneusma minus needle cast on Swiss mountain pine (Pinus uncinata) in Italy. Journal of Plant Pathology 93: 4 (Supplement), S4.63-S4.89.

Guindon, S., Dufayard, J. F., Lefort, V., Anisimova, M., Hordijk, W. \& Gascuel, O. 2010. New algorithms and methods to estimate maximum-likelihood phylogenies: assessing the performance of PhyML 3.0. Systematic Biology 59: 307-321. https://doi.org/10.1093/sysbio/ syq010

Guindon, S. \& Gascuel, O. 2003. A simple, fast and accurate method to estimate large phylogenies by maximum-likelihood. Systematic Biology 52: 696-704. https://doi.org/10.1080/10635150390235520

Hall, T. A. 1999. BioEdit: a user-friendly biological sequence alignment editor and analysis program for Windows 95/98/ NT. Nucleic Acids Symposium Series 41: 95-98.

Hata, K. \& Futai, K. 1995. Endophytic fungi associated with healthy pine needles and needles infested by the pine needle gall midge Thecodiplosis japonensis. Canadian Journal of Botany 73: 384-390. https://doi.org/10.1139/b95-040

Hirose, D. \& Osono, T. 2006. Development and seasonal variations of Lophodermium populations on Pinus thunbergi needle litter. $M y$ coscience 47: 242-247. https://doi.org/10.1007/s10267-006-0299-3

Holdenrieder, O. \& Sieber, T. N. 1995. First report of Mycosphaerella dearnessii in Switzerland. European Journal of Plant Pathology 25: 293-295. https://doi.org/10.1111/j.1439-0329.1995.tb01014.x

Hou, Ch., Li, L. \& Piepenbring, M. 2009. Lophodermium pini-mugonis sp. nov. on needles of Pinus mugo from the Alps based on morphological and molecular data. Mycological Progress 8: 29. https:// doi.org/10.1007/s11557-008-0575-Z

Katoh, K. \& Standley, D. M. 2013. MAFFT multiple sequence alignment software version 7, improvements in performance and usability. Molecular Biology and Evolution 30: 772-780. https://doi. org $/ 10.1093 / \mathrm{molbev} / \mathrm{mst} 010$ 
Koukol, O., Pusz, W. \& Minter, D. 2015. A new species of Lophodermium on needles of mountain pine (Pinus mugo) from the Giant Mountains in Poland. Mycological Progress 14: 23. https://doi. org/10.1007/s11557-015-1038-y

Kowalski, T. 1982. Fungi infecting Pinus sylvestris needles of various ages. European Journal of Plant Pathology 12(3): 182-190. https:// doi.org/10.1111/j.1439-0329.1982.tb01392.x

Kowalski, T. 1988. Zur Pilzflora toter Kiefernnadeln. Zeitschrift für Mykologie 54(2): 159-173.

Kowalski, T. 1993. Fungi in living symptomless needles of Pinus sylvestris with respect to some observed disease processes. Journal of Phytopathology 139: 129-145. https://doi.org/10.1111/j.1439-0434.1993. tb01409.x

Kowalski, T. \& Domański, S. 1983. Występowanie i przyczyny odwierzchołkowego zamierania pędów Pinus nigra, P. silvestris i P. strobus w niektórych drzewostanach południowej Polski w latach 1979-1980. Acta Agraria et Silvestria series Silvestris 20: 19-34.

Kowalski, T. \& Zych, P. 2002. Fungi isolated from living symptomless shoots of Pinus nigra growing in different site conditions. Österreichische Zeitschrift für Pilzkunde 11: 107-116.

Kowalski, T., Boroń, P., Bartnik, C. \& Rossa, R. 2018. Morphological and molecular characterization of Leptomelanconium allescheri associated with necrotic lesions on Pinus mugo needles in the Polish Tatra Mountains. Forest Pathology 48(3): e12420. https://doi. org/10.1111/efp.12420

Kumar, S., Stecher, G., Li, M., Knyaz, C. \& Tamura, K. 2018. MEGA $\mathrm{X}$ : Molecular Evolutionary Genetics Analysis across computing platforms. Molecular Biology and Evolution 35: 1547-1549. https:// doi.org/10.1093/molbev/msy096

La Porta, N. \& Capretti, P. 2000. Mycosphaerella dearnessii, a Needle-cast Pathogen on Mountain Pine (Pinus mugo) in Italy. Plant Disease 84(8): 922 https://doi.org/10.1094/pdis.2000.84.8.922a

Lang, K. J. \& Holdenrieder, O. 1985. Nekrotische Flecken an Nadeln von Picea abies-ein Symptom des Fichtensterbens? European Journal of Forest Pathology 15(1): 52-58. https://doi. org/10.1111/j.1439-0329.1985.tb01042.x

Lutyk, P. 1978. Stan zdrowotny sosny kosówki (Pinus mughus Scop.) na terenie Tatrzańskiego Parku Narodowego. Sylwan 122(10): 51-57.

Map of Polish Tatra Mountains: https://mapa.szukacz.pl/mapnik.html [Accessed 14 May 2021]

Maschning, E. \& Pehl, L. 1994. Bedrohung autochthoner Latschen durch Dothistroma-Nadelbräune. Allgemeine Forstzeitschrift 49: 249-252.

Minter, D. W., Staley, J. M. \& Millar, C. S. 1978. Four species of Lophodermium on Pinus sylvestris. Transactions of the British Mycological Society 71: 295-301. https://doi.org/10.1016/s00071536(78)80110-7

Minter, D. W. \& Millar, C. S. 1980. Ecology and biology of three Lophodermium species on secondary needles of Pinus sylvestris. European Journal of Plant Pathology 10: 169-181 https://doi. org/10.1111/j.1439-0329.1980.tb00023.x

Minter, D. W. 1981. Lophodermium on pines. Mycological Papers 147: $1-54$.

Mróz, W. \& Perzanowska, J. 2004. Zarośla kosodrzewiny (Pinetum mugo). In: Herbich, J. (ed.). Poradniki ochrony siedlisk $i$ gatunków Natura 2000 - poradnik metodyczny. Tom 3. Murawy, taki, ziołorośla, wrzosowiska, zarośla, pp. 54-62. Wyd. Ministerstwo Środowiska, Warszawa.

Ortiz-Garcia, S., Gernandt, D. S., Stone, J. K., Johnston, P. R., Chapela, I. H., Salas-Lizana, R. \& Alvarez-Buylla, E. R. 2003. Phylogenetics of Lophodermium from pine. Mycologia 95(5): 846-859. https:// doi.org/10.2307/3762013

Pehl, L. \& Butin, H. 1992. Dothistroma septospora, a new fungus pest on Pinus mugo. Allgemeine Forst Zeitschrift der Wald 47: 758-760.
Pehl, L. 1995. Eine neue Kiefernkrankheit in der Bundesrepublik Deutschland. Nachrichtenblatt des Deutschen Pflanzenschutzdienstes 47: 305-309.

Pusz, W., Kita, W., Kaczmarek, A., Nowosad, K. \& Koukol, O. 2013. Choroby igieł kosodrzewiny (Pinus mugo) w piętrze subalpejskim Karkonoszy. Sylwan 157(10): 761-769.

Pusz, W., Zwijacz-Kozica, T. \& Kita, W. 2015. The assessment of the health status of the needles of the Mugo Pine (Pinus mugo) in selected locations of the Tatra National Park. Sylwan 159(5): 411-418.

Rambaut, A. \& Drummond, A. J. 2007. Tracer v1.4. http://beast.bio. ed.ac.uk/Tracer [Accessed 8 Mar. 2019]

Reignoux, S. N., Green, S. \& Ennos, R. A. 2014. Molecular identification and relative abundance of cryptic Lophodermium species in natural populations of Scots pine, Pinus sylvestris L. Fungal Biology 118: 835-845. https://doi.org/10.1016/j.funbio.2014.07.002

Ronquist, F. \& Huelsenbeck, J. P. 2003. MrBayes 3: Bayesian phylogenetic inference under mixed models. Bioinformatics 19: 1572-1574. https://doi.org/10.1093/bioinformatics/btg180

Saikkonen, K., Faeth, S. H., Helander, M. \& Sullivan, T. J. 1998. Fungal endophytes: A continuum of interactions with host plants. Annual Review of Ecology, Evolution, and Systematics 29: 319-343. https:// doi.org/10.1146/annurev.ecolsys.29.1.319

Salas-Lizana, R. \& Oono, R. 2018. A comparative analysis of Lophodermium fissuratum, sp. nov., found in haploxylon pine needles in the Pacific Northwest, and other Lophodermium endophytes. Mycologia 110(5): 797-810. https://doi.org/10.1080/00275514.2018.1499991

Schnell, G. R. 1987. Investigations of plant diseases in reforestations of the subalpine region in the central Swiss Alps. European Journal of Forest Pathology 17: 19-33. https://doi. org/10.1111/j.1439-0329.1987.tb00724.x

Schütt, P., Koch, W., Blaschke, H., Lang, K. J., Reigber, E., Schuck, H. J. \& Summerer, H. 1985. So stirbt der Wald. Schadbilder und Krankheitsverlauf. BLV Verlaggeselschaft, München.

Sieber, T. N., Ryś, J. \& Holdenrieder, O. 1999. Mycobiota in symptomless needles of Pinus mugo ssp. uncinata. Mycological Research 103: 306-310. https://doi.org/10.1017/S0953756298007229

Sieber, T. N. 2007. Endophytic fungi in forest trees: are they mutualists? Fungal Biology Reviews 21: 75-89. https://doi.org/10.1016/j. fbr.2007.05.004

Sutton, B. C. 1980. The coelomycetes. Fungi imperfecti with pycnidia, acervuli and stromata. Kew Surrey, UK: CMI.

Sutton, B. C. \& Chao, R. L. C. 1970. Leptomelanconium. Transactions of the British Mycological Society 55(1): 37-44. https://doi. org/10.1016/ S0007-1536(70)80093-6

Swofford, D. L. 2003. PAUP*. Phylogenetic analysis using parsimony ( ${ }^{*}$ and other methods). Version 4. Sinauer Associates, Sunderland.

Tamura K., Nei, M. \& Kumar, S. 2004. Prospects for inferring very large phylogenies by using the neighbor-joining method. Proceedings of the National Academy of Sciences (USA) 101: 11030-11035. https://doi.org/10.1073/pnas.0404206101

Wang, S-J., Lin, Y-R., Hou, C-L., Gao, X-M., Yang, Z-Z. \& Liu, F. 2010. A preliminary study on phylogeny of Lophodermium based on rDNA-ITS sequences. Mycosystema 29: 199-205.

White, T. J., Bruns, T., Lee, S. \& Taylor, J. W. 1990. Amplification and direct sequencing of fungal ribosomal RNA genes for phylogenetics. In: Innis, M. A., Gelfand, D. H., Sninsky, J. J. \& White, T. J. (eds), PCR protocols: A guide to methods and applications, pp. 315-322. New York, NY: Academic Press Inc. https://doi.org/10.1016/b978012-372180-8.50042-1

Wieser, G., Manning, W. J., Tausz, M. \& Bytnerowicz, A. 2005. Evidence for potential impacts of ozone on Pinus cembra L. at mountain sites in Europe: an overview. Environ Pollution 139(1): 53-58. https://doi.org/10.1016/j.envpol.2005.04.037.

Vujanovic, V. \& St-Arnaud, M. 2001. Leptomelanconium abietis sp. nov. on needles of Abies balsamea. Mycologia 93(1): 212-215. https://doi.org/10.1080/00275514.2001.12063150 